DE

M E D I C I N A

T R O P I C A L

DE

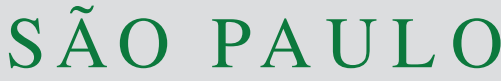

JOURNAL OF THE SÃO PAULO INSTITUTE OF TROPICAL MEDICINE

${ }^{1}$ Hospital Municipal de Santarém, Santarém, Pará, Brazil

¿Universidade de São Paulo, Faculdade de Medicina, Departamento de Moléstias Infecciosas e Parasitárias, Núcleo de Medicina Tropical, São Paulo, São Paulo, Brazil

${ }^{3}$ Secretaria Municipal de Saúde de Diadema, Centro de Referência em Infecções Sexualmente Transmissíveis, Aids e Hepatites Virais, Diadema, São Paulo, Brazil

${ }^{4}$ Universidade de São Paulo, Hospital das Clínicas, Laboratório de Imunopatologia da Esquistossomose e Outras Parasitoses (LIM-06), São Paulo, São Paulo, Brazil

[Universidade de São Paulo, Hospital das Clínicas, Laboratório de Investigação Médica em Imunologia (LIM-48), São Paulo, São Paulo, Brazil

${ }^{6}$ Universidade de São Paulo, Instituto de Medicina Tropical de São Paulo, São Paulo, São Paulo, Brazil

Correspondence to: Francisco Oscar de Siqueira França

Universidade de São Paulo, Hospital das Clínicas, Laboratório de Investigação Médica em Imunologia (LIM-48),

Av. Dr. Enéas de Carvalho Aguiar, 470, Térreo, CEP 05403-000, São Paulo, SP, Brazil

E-mail: fosfranca@usp.br

Received: 30 June 2020

Accepted: 14 October 2020

\section{Unusual case of lagochilascariasis with breast involvement: the first case report in pregnancy}

\author{
João Guilherme Pontes de Lima Assy ${ }^{\circledR 1,2}$, Helena Rangel Esper ${ }^{\circledR 1,2}$, \\ Mariana Margarita Martinez Quiroga ${ }^{1,2}$, Alisson dos Santos Brandão ${ }^{(1,2}$, \\ Renato do Carmo Said ${ }^{1,2}$, Olívia Campos Pinheiro ${ }^{(1,2}$, Adriana Paulino \\ da Silva Ribeiro ${ }^{3}$, Maria Cristina Carvalho do Espírito Santo ${ }^{4,6}$, \\ Francisco Oscar de Siqueira França ${ }^{\circledR 2,5,6}$
}

\section{ABSTRACT}

Lagochilascariasis is a neglected neotropical helminthiasis, responsible for human infections through the ingestion of raw or undercooked meat from wild animals infected by larvae encysted in their tissues. It is characterized by a chronic evolution with periods of remission and recurrences, affecting mainly the head and neck regions. It can progress to death by invasion of the central nervous system. It is caused by the Lagochilascaris minor nematode, first described in 1909 and mainly found in the Brazilian Amazon ecosystem, notably in Para State. In May 2010, a 15-year-old female, born in the city of Aveiro, Para State, was hospitalized in the city of Santarem, Para State, presenting with cervical and spinal abscesses and osteolytic lesions at T3-T5 level. During hospitalization, white larvae identified as L. minor were observed in a cervical subcutaneous fistula. After the surgical drainage of abscesses, albendazole $400 \mathrm{mg}$ /day was started, with improvement of symptoms. The patient abandoned the follow-up and in January 2016, during the $20^{\text {th }}$ week of pregnancy, she was readmitted to the Santarem Municipal Hospital with new cervical abscesses in the infra-mammary region, with numerous larvae exiting by subcutaneous left breast fistulas. The antiparasitic treatment was restarted due to possible reactivation of the infection in the spine and dissemination to the central nervous system. Ten weeks after hospital discharge, the patient had resolution of the fistulas and decreased abscesses, without gestational complications. This is the first case report of lagochilascariasis during pregnancy, as well as of involvement of mammary glands.

KEYWORDS: Lagochilascariasis. Lagochilascaris minor. Helminthiasis. Pregnancy. Breast. Thoracic spine.

\section{INTRODUCTION}

Lagochilascariasis is a parasitic infection whose etiological agent is a nematode helminth (Nematoda) of the order Ascoroidea, family Ascarididae, genus Lagochilascaris, that comprises six species, however only Lagochilascaris minor, can cause human disease. It was initially identified and described by Robert T. Leiper in 1909, based on two cases observed in Trinidad and Tobago ${ }^{1-3}$. Since this initial report, cases have been reported in tropical and subtropical areas of Latin America, from Southern Mexico to Argentina and the Caribbean islands ${ }^{4}$. Most reports were published in Brazil, particularly in Para State. This parasitosis was firstly reported in the Amazon Region in 1978, ten years after its first description on national soil 5 . 
In the transmission cycle, natural hosts which are probably wild carnivores (felids), eliminate the parasite eggs in feces that contaminate the soil. These embryonic eggs are ingested by other animals (probably rodents), resulting in infection with larvae and encysted forms developing in their tissues, thus being intermediate hosts that are mandatory for maintaining the natural zoonotic cycle of the species ${ }^{3,6}$.

Men domestic dogs and cats become infected by ingesting the L3 larvae encysted in muscles, viscera or subcutaneous tissues of raw or undercooked meat of these intermediate hosts (wild animals), behaving as definitive accidental hosts. The helminth reaches the digestive tract, ascends through the respiratory tract and migrates to the surrounding regions, such as lymph nodes and sinuses ${ }^{5,6}$. Thus, human beings start to host adult, egg and larval forms of the parasite that are able to reproduce successive cycles, in an autoinfection process that will result in a chronic parasitic infectious condition.

The worm has tropism for the subcutaneous tissue of the neck, paranasal sinuses and mastoid, although it may migrate to other regions. In severe forms, the infection can compromise bones, lungs and the central nervous system ${ }^{3,5}$. Treatment is often unsatisfactorydue to the recurrence of lesions months or years after an apparent clinical cure ${ }^{2,5}$.

We performed a systematic review of the following electronic interdisciplinary databases: Scopus, PubMed, Virtual Health Library (VHL) and Latin American and Caribbean Health Sciences Information Center (LILACS) using the following search terms: Lagochilascaris, Lagochilascariasis and Pregnancy, Lagochilascariasis and Spine, Lagochilascariasis and Thoracic vertebrae, Lagochilascariasis and breast, Lagochilascariasis and Mammary gland.No articles were found in these databases reporting the presence of Lagochilascariasis in pregnant women, or involvement of breasts or thoracic spine.

In addition, a review article performing a bibliographic analysis of human lagochilascariasis from 1909 to 2001, found 109 cases exclusively reported in Tropical America, but failed to find any scientific article on human lagochilascariasis in pregnancy or with breast or thoracic spine involvement ${ }^{7}$.

This case report was approved by the Ethics and Research Committee of the Department of Infectious and Parasitic Diseases of the Faculty of Medicine of the University of Sao Paulo, process $N^{\circ} 002 / 20$ on May $13^{\text {th }}$, 2020 .

\section{CASE REPORT}

A 21-year-old, of mixed ethnicity female, born in Aveiro, Para State, was admitted to the Santarem Municipal Hospital (HMS) located in Santarem. Para State, Brazil, in January 2016. She was in the $20^{\text {th }}$ week of pregnancy with abscesses in the right and left cervical regions and in the left infra- mammary region that were noticed by the patient a month before. Upon physical examination, the patient was in regular general condition, conscious, weighing $34 \mathrm{~kg}$, and was pallid $+2 /+4$. She had an extensive right cervical mass with fluctuation areas along its entire length, measuring about $10 \mathrm{~cm}$; and two fistulized lesions: one nodular in the left cervical region and one under the left breast, both presenting with a milky discharge (Figures 1A, 1B, 1C). Numerous helminths were found in these lesions (Figures 2A, 2B and 2C). The patient presented an enlarged abdomen compatible with pregnancy.

She has also reported a history of cervical and spinal abscesses that appeared between mid-2008 and 2009 and

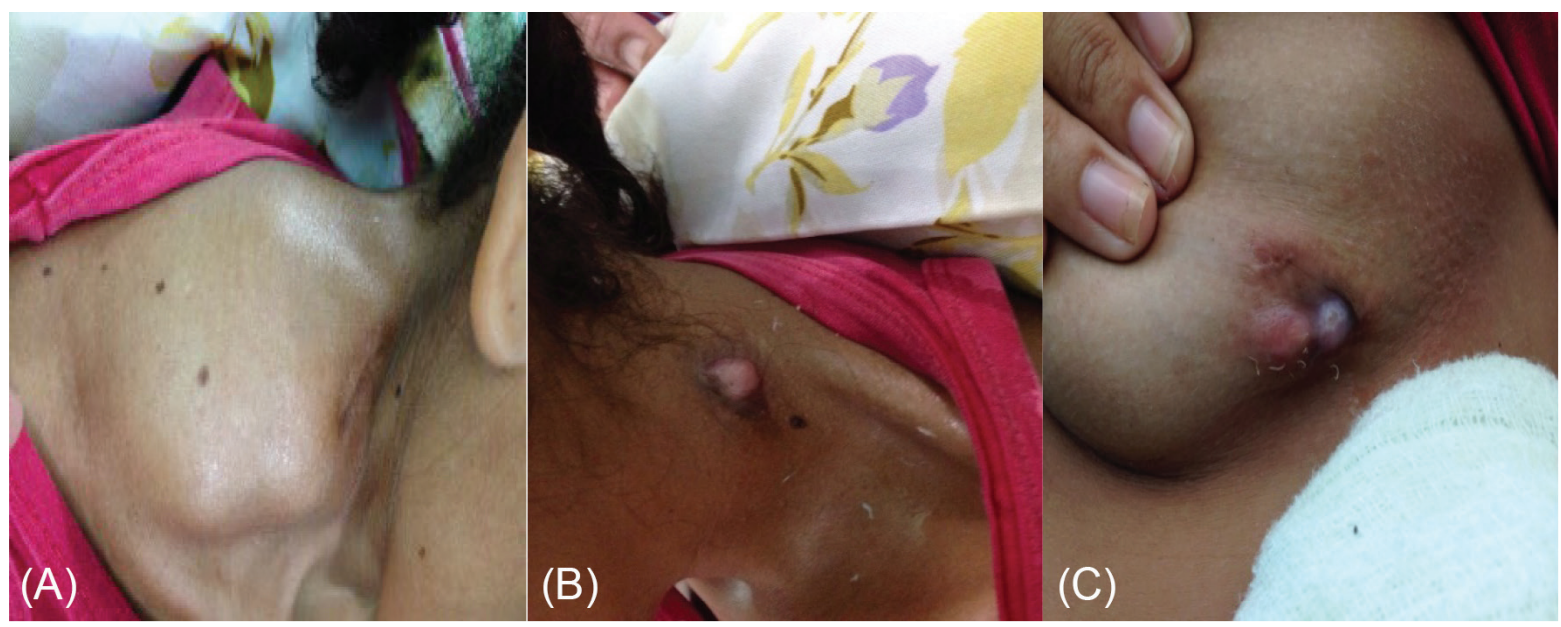

Figure 1 - (A) Extensive right cervical nodular lesion with fluctuation areas along its entire length, measuring about 10 centimeters; (B) Abscess in the left cervical region, with exit of numerous milky-white larvae through subcutaneous fistulas; (C) Abscess in the infra-mammary region, with numerous milky-white helminths emerging from subcutaneous fistulas on the left breast. 

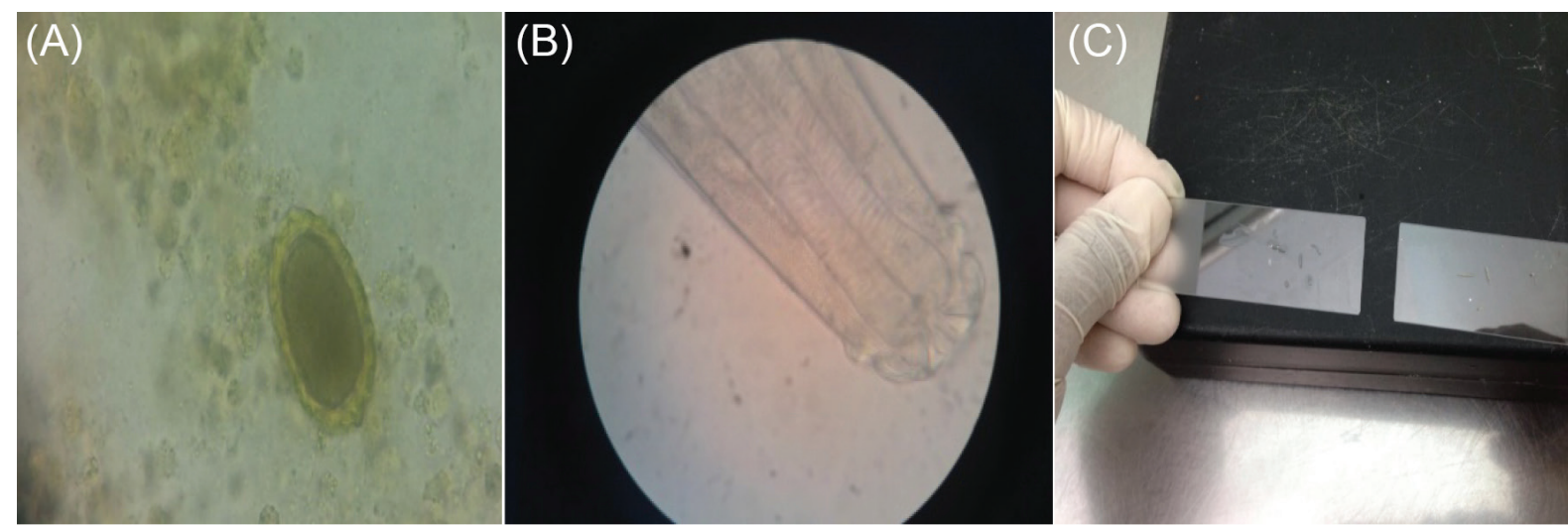

Figure 2 - (A) Lagochilascaris minor egg, seen under the microscope, collected from secretions of lesions; (B) Lagochilascaris minor, seen under a microscope, collected from secretions of lesions; (C) Lagochilascaris minor, seen under a microscope, collected from secretions of lesions.

she was admitted to the Baixo Amazonas do Para Regional Hospital in Santarem, Para State, in May 2010. Bone destruction at the T3-T5 level and the presence of white larvae coming out of cervical subcutaneous fistula were identified as Lagochilascaris minor. At that time, she started treatment with albendazole $400 \mathrm{mg} /$ day and underwent a surgical procedure to drain the abscesses, resulting in improvement of symptoms, but the follow-up was subsequently abandoned. She denied any autoimmune diseases, malignancies, HIV infection, immunosuppression by drugs, or diabetes mellitus. The patient reported that she had eaten game meat a few times in the past, especially Paca (Cuniculus paca), a habit that she discontinued many years ago.

Results of laboratory tests showed $8.4 \mathrm{~g} / \mathrm{dL}$ hemoglobin, $23.7 \%$ hematocrit, $71.17 \mathrm{fl}$ mean corpuscular volume; $25.2 \mathrm{pg}$ mean corpuscular hemoglobin (HCM; $35.4 \mathrm{~g} / \mathrm{dL}$ mean corpuscular hemoglobin concentration (CHCM); 3,600 leukocytes $/ \mathrm{mm}^{3}$ with normal differential count; 336,000 platelets $/ \mathrm{mm}^{3} ; 108 \mathrm{U} / \mathrm{L}$ alkaline phosphatase; $53 \mathrm{U} / \mathrm{L}$ GT range; $31 \mathrm{U} / \mathrm{L}$ aspartate aminotransferase (AST); $22 \mathrm{U} / \mathrm{L}$ alanine aminotransferase (ALT); $0.2 \mathrm{mg} / \mathrm{dL}$ total bilirubin; $0.11 \mathrm{mg} / \mathrm{dL}$ direct bilirubin; $5.87 \mathrm{~g} / \mathrm{dL}$ total proteins; $15 \mathrm{mg} / \mathrm{dL}$ urea; $0.34 \mathrm{mg} / \mathrm{dL}$ creatinine; $140 \mathrm{~mm} / \mathrm{h}$ Erythrocyte Sedimentation Rate (ESR); 723 U/L lactic dehydrogenase (DHL).

Secretions of the lesions were sampled and analyzed by microscopy. Slides showed eggs, larvae and adult forms of Lagochilascaris minor, confirming the diagnosis of lagochilascariasis. Treatment was restarted and maintained throughout the hospitalization period, with albendazole and ivermectin used exclusively as anthelmintic drugs. The surgical drainage of the abscesses was also carried out and the patient evolved without any complications until the end of the pregnancy. Ten weeks after hospital discharge, the patient had resolution of the fistulas and decreased abscesses.

\section{DISCUSSION}

Brazil has the highest number of registered lagochilascariasis cases, representing $78.1 \%$ (100/128) of the known cases worldwide. The majority of cases in Brazil $(60 \%, 60 / 100)$ were registered in Para State, corresponding to $46.9 \%$ of the worldwide total ${ }^{2,5}$.

This patient is from Aveiro, in Para State, a city located in the Mesoregion of Southwest Para. The Aveiro human development index (HDI) is low (0.541), and has its origins in a Mundurucu indigenous village ${ }^{8}$. Currently, a large part of the municipal economy is based on the Tapajos-Arapiuns Extractive Reserve, an area intended for traditional local populations, whose survival is based on extraction and subsistence agriculture and small animal farming ${ }^{9}$. Although the patient denied eating game meat, this practice is still common in many riverside, forest and indigenous populations that inhabit the region.

The helminth causes lesions (nodules, fistulas, cutaneous and subcutaneous abscesses), and in this report, lesions were characterized as right (Figure 2A) and left (Figure 2B) cervical nodules and nodules under the left breast (Figure 2C). According to the literature review, cases mostly occur in cervical and mastoid regions, paranasal sinuses, middle ear, rhinopharynx, oropharynx and skull base. There are also cases described of lesions in the central nervous system, sacral region, eyeballs, Eustachian tube, chin, submandibular and supraclavicular regions, scapular muscles, cervical vertebrae, dental alveoli, lungs, cranial nerves, among others $\mathrm{s}^{2,3,5,7,10-12}$. In this case report the patient also presented with involvement of thoracic spinal vertebrae.

Identification is usually, and in this report, based on the finding of the nematode parasite eggs (Figure 2A), larvae (Figure 2B) and adult parasites (Figure 2C) in lesion secretions. 
The lagochilascariasis etiologic agent, L. minor, is a small ascarid nematode of up to $20 \mathrm{~mm}$ in the adult form, milky white in color and a mouth trimmed by three welldeveloped lips, separated by interlabial membranes, which give the end of the head a characteristic aspect reminiscent of a cleft lip (lago = hare; chil = lip) (Figures $2 \mathrm{~B}$ and 2C) $)^{2,6,11,12}$.

In this case, the patient was treated with a combination of albendazole and ivermectin in association with drainage of abcesses. The antiparasitic treatment was restarted despite the possible risk to the fetus, considering the possibility of reactivation in the spine and possible placental invasion.

The literature has reported the use of other drugs such as diethylcarbamazine, thiabendazole, mebendazole, cambendazole, levamisole and praziquantel, individually or in combinations, with or without associated surgical procedures. However, it is very common to find no definite cure, as recurrences are frequent even after treatment, and lesions may resurface months or years after an apparent clinical cure, which can be explained by the inability of existing drugs to eliminate the presence of L. minor eggs in the lesions, allowing auto-infection to recur ${ }^{2,5,13-15}$.

Ten weeks after hospital discharge, the patient had fistula resolution and decreased abscesses. There were no gestational complications related to the disease or its treatment.

The differential diagnosis of these lesions are ganglion and pulmonary tuberculosis, other non-tuberculous mycobacterioses, neoplasms of the head or neck, suppurative otitis media, mastoiditis and sinusitis of other etiologies, pyogenic adenitis, paracoccidioidomycosis, actinomycosis and leishmaniasis, among others ${ }^{5,16,17}$.

In our case, chronic breast diseases and frequent causes of chronic spinal involvement such as Pott's disease and bacterial vertebral osteomyelitis need to be added to the above etiologies as differential diagnoses.

The involvement of bone tissue in the base of the skull region, sinuses, mastoiditis and the ability of the disease to progress to neighboring regions overcoming bone barriers is already known. However, remote bone involvement of the head and neck has been rarely described.

The largest database of symptomatic lagochilascariasis cases contained 123 reports up to October 2009 and referred to one case with lesions in the sacrum and iliac fossa region ${ }^{18}$.

In 2001, there was a case described of a young female patient from Roraima State (Brazil) whose evolution included erosion of the occipital bone and of the first cervical vertebra on tomographic examination ${ }^{19}$. In 2016, a case of a patient in Suriname with base of the skull involvement and chronic recurrence after treatment was reported ${ }^{11}$.
The involvement of the spine was also noteworthy in this patient, more specifically the simultaneous involvement of three thoracic vertebrae (T3-T5), probably due to the spread and long evolution of the helminthiasis without treatment.

As far as we know, this is the first case report of lagochilascariasis during pregnancy, and there are no previous records of involvement of the mammary gland and thoracic vertebrae in the same patient.

Although no gestational complications were found in this patient, we consider that further studies on the immunopathogenesis of the disease and its evolution in pregnant women and patients with compromised immunity are necessary, as well as the study on the way the disease spreads to regions other than the head and neck, as seen in this patient. Perhaps the spread of helminthiasis to the left breast and thoracic spine could be explained by contiguous dissemination corroborated by osteolysis, a prominent characteristic of this helminthiasis ${ }^{20}$.

The best way to control this disease is prevention. The consumption of game meat, especially rodents, is therefore not recommended, but in the case of real need, cooking the meat at $100{ }^{\circ} \mathrm{C}$ for $10 \mathrm{~min}$ and/or freezing it at $-20{ }^{\circ} \mathrm{C}$ for 15 days could be a way to prepare meat for human consumption $^{5,6}$.

There is a strong need to monitor the evolution of lagochilascariasis over a long period of time due to the possible recurrence of the disease many years after the initial diagnosis, and also to determine the most effective treatment. Moreover, the well-known underreporting of this disease requires health professionals to be made aware of the disease many manifestations, a continuous surveillance program for early diagnosis, implementation of diagnostic techniques to understand its real prevalence and preventive measures to help reducing its occurrence in Brazil, and especially Para State.

\section{AUTHORS' CONTRIBUTIONS}

JGPLA, HRE, MMMQ, ASB, RCS, OCP and APSR were responsible for the diagnosis, assistance during the hospitalization and treatment of the patient. They prepared the summary of the case and supported the preparation of the article. MCCES and FOSF carried out the entire bibliographic review, wrote and elaborated the discussion of the article. All authors made critical suggestions, analyzed and agreed with the final presentation of the article.

\section{REFERENCES}

1. Leiper RT. A new nematode worm from Trinidad: Lagochilascaris minor. Proc Zool Soc Lond. 1909;4:742-3. 
2. Leão RN, Fraiha-Neto H. Lagoquilascaríase. In: Tavares E, Marinho LA, editores. Rotinas de diagnóstico e tratamento das doenças infecciosas e parasitárias. $4^{\mathrm{a}}$ ed. São Paulo: Atheneu; 2015. p.724-8.

3. Campos DM, Barbosa AP, Oliveira JA, Tavares GG, Cravo PV, Ostermayer AL. Human lagochilascariasis: a rare helminthic disease. PLoS Negl Trop Dis. 2017;11: e0005510.

4. Barrera-Pérez M, Manrique-Saide P, Reyes-Novelo E, EscobedoOrtegón J, Sánchez-Moreno M, Sánchez C. Lagochilascaris minor Leiper, 1909 (Nematoda: Ascarididae) in Mexico: three clinical cases from the Peninsula of Yucatan. Rev Inst Med Trop Sao Paulo. 2012;54:315-7.

5. Leão RN, Leão Filho J, Braga-Dias L, Calheiros LB. Infecção cutânea pelo Lagochilascaris minor Leiper, 1909: registro de um caso observado no estado do Pará (Brasil). Rev Inst Med Trop Sao Paulo. 1978;20:300-6.

6. Barreto LF, D'Anunciação L, Plisker P, Werkema F, Berenstein CK. Lagochilascariasis: case report. J Bras Patol Med Lab. 2018;54:245-8.

7. Palheta Neto FX, Leão RN, Fraiha-Neto H, Tomita S, Lima MA, Pezzin-Palheta AC. Contribuição do estudo da lagochilascaríase humana. Rev Bras Otorrinolaringol. 2002;68:101-5.

8. Instituto Brasileiro de Geografia e Estatística. Brasil/Pará/Aveiro. [cited 2020 Oct 14]. Available from: https://cidades.ibge.gov. br/brasil/pa/aveiro/panorama

9. Instituto Socioambiental. Reserva Extrativista Tapajós-Arapiuns. [cited 2020 Oct 14]. Available from: https://uc.socioambiental. org/arp/1353

10. Moraes MA, Arnaud MV, Macedo RC, Anglada AE. Infecção pulmonar fatal por Lagochilascarissp., provavelmente Lagochilascaris minor Leiper, 1909. Rev Inst Med Trop Sao Paulo. 1985;27:46-52.

11. Douma JA, Akrum RA, Joe RT, Chan M, Codrington J, Vreden SG.
A case of lagochilascariasis in Suriname with the involvement of the ENT system and the skull base. Am J Trop Med Hyg. 2016;95:88-91.

12. Cardoso CB, Neves JH, Amarante AF. Lagochilascaris minor (Nematoda, Ascarididae) in a domestic cat in a coastal city of the state of São Paulo. Vet Parasitol Reg Stud Reports. 2020;19:100372.

13. Oostburg BF. Thiabendazole therapy of Lagochilascaris minor infection in Surinam: report of a case. Am J Trop Med Hyg. 1971;20:580-3.

14. Orihuela R, Botto C, Delgado O, Ortiz A, Suarez JA, Arguello C. Lagochilascariasis humana en Venezuela: descripción de un caso fatal. Rev Soc Bras Med Trop. 1987;20:217-21.

15. Campos DM, Freire Filha LG, Vieira MA, Paçô JM, Maia MA. Experimental life cycle of Lagochilascaris minor Leiper, 1909. Rev Inst Med Trop Sao Paulo. 1992;34: 277-87.

16. Paçô JM, Campos DM. Lagochilascaris minor Leiper, 1909: nove décadas de revisão bibliográfica. Rev Patol Trop. 1998;27:11-34.

17. Maquiné GA, Wanderley BR, Melo TN, Wanderley RB, Barreto RA. Lagoquilascaríase humana: um diagnóstico a ser lembrado diante de tumoração de cabeça e pescoço: relato de caso. Rev Soc Bras Clin Med. 2018;16:45-7.

18. Fraiha-Neto H, Leão RN. Lagochilascaríase. In: Coura JR, editor. Dinâmica das doenças infecciosas e parasitárias. $2^{\text {a }}$ ed. Rio de Janeiro: Guanabara-Koogan; 2018. p.1125-30.

19. Faria CF, Távora HR, Trovão C, Fortes A, Shozuka MA, Santa Cruz MJ. Lagoquilascaríase com invasão de coluna cervical. J Bras Med. 2001;80:24-6.

20. Aquino RT, Magliari ME, Vital Filho J, Silva MA, Lima $\mathrm{CA}$, Rocha AJ, et al. Lagochilascariasis leading to severe involvement of ocular globes, ears and meninges. Rev Inst Med Trop Sao Paulo. 2008;50:355-8. 